\title{
The effect of alpha fetoprotein on NF-кB translocation in lipopolysaccharide induced monocyte-derived dendritic cell
}

\author{
Akterono D. Budiyati, ${ }^{1}$ Agus Setiyono, ${ }^{2}$ Elpita Tarigan, ${ }^{1}$ Heri Wibowo ${ }^{3}$ \\ ${ }^{1}$ Division of Immunology, Mochtar Riady Institute for Nanotechnology, Tangerang, Indonesia \\ ${ }^{2}$ Division of Pathology, Department of Clinic, Reproduction and Pathology, Bogor Agricultural University, Bogor, Indonesia \\ ${ }^{3}$ Department of Immunology, Biomedical Graduate Program, Faculty of Medicine, Universitas Indonesia, Jakarta, Indonesia
}

\begin{abstract}
Abstrak
Latar belakang: Alfa fetoprotein (AFP) merupakan antigen onkofetal yang berperan penting dalam perkembangan ontogenik dan onkogenik. Kadar AFP dalam darah pasien hepatocellular carcinoma (HCC) diketahui meningkat dibandingkan orang sehat. Publikasi terakhir menunjukkan bahwa AFP menyebabkan disfungsi sel dendritik derivat monosit sebagai antigen presenting cell $(A P C)$ yang dapat mengakibatkan respon antitumor menjadi tidak efisien. Penelitian pendahuluan ini bertujuan untuk mengetahui apakah efek AFP terhadap disfungsi sel dendritik derivat monosit sebagai APC adalah melalui jalur sinyal $N F-\kappa B$ dengan menggunakan lipopolisakarida (LPS) sebagai penginduksi aktifasi $N F-\kappa B$.
\end{abstract}

Metode: Sel monosit dikultur dalam medium yang mengandung GM-CSF $(800 \mathrm{ng} / \mathrm{mL})$ dan $\mathrm{IL}-4(1000 \mathrm{ng} / \mathrm{mL})$ dengan atau tanpa penambahan AFP dan diinkubasi selama enam hari agar berdiferensiasi menjadi sel dendritik imatur. Sel dendritik matur kemudian diperoleh dengan menambahkan LPS ke kultur dan diinkubasi selama 30 menit. Deteksi translokasi NF- $k B$ dilakukan menggunakan uji imunofluoresens (IFA).

Hasil: Pada kelompok kontrol, induksi LPS menyebabkan terjadinya translokasi NF- $\mathrm{B} B$ sedangkan kelompok AFP menunjukkan hasil yang berlawanan yaitu translokasi $N F-\kappa B$ tidak terjadi.

Kesimpulan: Penelitian ini menunjukkan bahwa AFP mencegah aktifasi dan translokasi $N F-\kappa B$ sehingga menyebabkan gangguan fungsi sel dendritik derivat monosit sebagai APC. Hasil yang diperoleh diharapkan memberikan pemahaman baru mengenai peran AFP dalam mekanisme supresi respon antitumor. (Med J Indones. 2012;21:97-101)

\begin{abstract}
Background: Alpha fetoprotein (AFP) is a tumor-associated Ag that has a function in both ontogenic and oncogenic growth and its serum level is elevated in patients with hepatocellular carcinoma (HCC). A recent study showed that the immunoregulatory effect of AFP was through impairment of dendritic cell function as antigen presenting cell (APC), a mechanism that is known to hamper efficient antitumor response. However, the underlying intracellular mechanism of action of AFP required elucidation. As an initial step to determine the signaling pathway of AFP, we analyzed whether LPS induced NF- $\mathrm{KB}$ translocation occured in AFP-treated monocyte-derived dendritic cell (MDDC), which was induced by lipopolysaccharide (LPS).

Methods: Monocytes were cultured in GM-CSF $(800 \mathrm{ng} / \mathrm{mL})$ and IL-4 $(1000 \mathrm{ng} / \mathrm{mL})$ containing medium and incubated for six days to generate immature MDDCs with or without the presence of AFP. Mature MDDC was generated by stimulation of the immature MDDC with LPS for another 30 minutes. The analysis of NF- $\mathrm{KB}$ translocation was measured by fluorescent microscopy.

Results: Following activation of MDDC by LPS, the control group showed a marked nuclear staining of NF- $\kappa \mathrm{B}$. However, the AFP-treated group showed negative nuclear staining similar as observed in unactivated MDDC.

Conclusion: This study demonstrated that AFP prevented the activation and nuclear translocation of NF- $\mathrm{KB}$ and subsequently might cause the impairment of MDDC function as APC. This finding provides a new insight on the role of AFP in the suppression mechanism of anti tumor immune response. (Med J Indones. 2012;21:97-101)
\end{abstract}

Keywords: Alpha fetoprotein, dendritic cell, lipopolysaccharide, $N F-\kappa B$ translocation

Alpha fetoprotein (AFP) is a $70 \mathrm{kDa}$ oncofetal protein and is detected both fetally and maternally during pregnancy and then its expression is turned off completely after birth. ${ }^{1}$ AFP is thought to play an intrinsic immunomodulator capacity to avoid rejection of the developing embryo by maternal immune system. ${ }^{1,2}$ Our previous study revealed this immunomodulatory properties of AFP might happen through the impairment of monocytes-derived dendritic cell (MDDC) as antigen presenting cell (APC). ${ }^{3}$ A majority of hepatocellular carcinoma (HCC) patients have high level of AFP in their serum and tumor tissue, ${ }^{2}$ and increase in AFP might cause the dysfunction of DC. Dysfunction of DC is one of the critical mechanisms to escape immune surveillance. ${ }^{4}$

Since our previous report proved that alpha fetoprotein (AFP) inhibited synthesis of interleukin-12 (IL-12) ${ }^{3}$ and NF- $\kappa \mathrm{B}$ is the transcription factor of IL-12, ${ }^{5}$ we assumed that nuclear factor kappa B (NF- $\mathrm{B}$ ) was involved in this mechanism. In order to deepen our understanding on intracellular mechanism affected by 
AFP, we conducted a study to determine which element in NF- $\kappa$ B signaling pathway that was directly inhibited by AFP. This preliminary report aimed to determine the effect of AFP on nuclear translocation of NF- $\kappa B$ using lipopolysaccharide (LPS) as activator for $\mathrm{NF}-\kappa \mathrm{B}$ signaling pathway. ${ }^{5}$

\section{METHODS}

The experiment was designed as analytical laboratory experiment and was carried out at Mochtar Riady Institute for Nanotechnology (MRIN) laboratory. Informed consents were obtained from the donors, and the ethical approval was granted from the Committee on Health Research Ethics of MRIN.

\section{Samples}

A total of $30 \mathrm{~mL}$ blood was used in this study and was obtained by phlebotomy procedure from 3 healthy volunteers $(n=3)$ with the age of 25 to 35 years old. We used vacutainer ${ }^{\circledR}$ with heparin (BD vacutainer) during the phlebotomy procedure. The peripheral blood mononuclear cells (PBMCs) were then prepared by separating the phlebotomy product using Ficoll-hypaque (GE Health Care, UK) density gradient separation. ${ }^{3}$ In brief, blood was suspended in equal volume of phosphate buffer saline (PBS) and then layered on ficoll solution with ratio $4: 3$ (blood suspension/ficoll volume). Centrifugation was then performed at 2500 rotation per minute (RPM) for 30 minutes. PBMCs were then collected as a cloudy ring trapped between ficoll and plasma suspension. The PBMCs were then washed twice in PBS and spinned at 2000 RPM for 10 minutes.

\section{Generation of monocyte-derived dendritic cells (MDDCs)}

MDDCs were generated as described previously ${ }^{3}$ with some modifications. In brief, PBMCs from each volunteer were adhered to 12 well culture plates with a density of $1 \times 10^{6} / \mathrm{mL}$ for 30 minutes at $37^{\circ} \mathrm{C}$ with $5 \% \mathrm{CO} 2$. The non adherent cells were removed by gentle wash and the adherent cells were then cultured in complete medium RPMI 1640 (Sigma) supplemented with 10\% heat-inactivated fetal bovine serum (Gibco), and rhGM-CSF (800 U/mL, BD Bioscience Pharmingen) and rh-IL-4 (1000 U/mL, BD Bioscience Pharmingen] for another 6 days. Where indicated, purified human cord blood AFP (FL-AFP, purity > 95\%; Monobind method; Lee Biosolutions, Inc) was added at day 0. Based on our previous result, concentration of AFP $6.25 \mu \mathrm{g} / \mathrm{mL}$ gave a significance suppression effect to MDDCs, but still produced cells with viability $>90 \%$ compared to the non
AFP-treated cells (control). ${ }^{3}$ The concentration of 6.25 $\mu \mathrm{g} / \mathrm{mL}$ was then used for all subsequent experiments.

\section{Cell stimulation}

NF- $\kappa \mathrm{B}$ activation was performed as described previously. ${ }^{6}$ In brief, immature MDDCs were activated by adding $1000 \mathrm{ng} / \mathrm{mL}$ LPS from Escherichia coli (serotype 0111:B4; Sigma) and incubated for 30 minutes, one hour, four hours, or 24 hours respectively.

\section{Detection of NF-кB translocation}

From our previous study, we found that concentration of $6.25 \mu \mathrm{g} / \mathrm{mL}$ is the limit of significance of the suppressive effect of AFP on MDDCs. ${ }^{3}$ The same concentration was used to detect NF- $\kappa \mathrm{B}$ translocation. In order to observe the nuclear translocation of $\mathrm{NF}-\kappa \mathrm{B}$, the MDDCs of each group were harvested and then pelleted by centrifugation in microcentrifuge tubes for 3 minutes at 3500 RPM. The pellet was then washed twice with PBS using similar centrifugation procedure. After washing, the pellet was resuspended in PBS and smeared on poly L-lysine glass slide. Fixation was performed on air dried smeared cells using acetone for 10 minutes. The cells were then incubated in phosphate buffered saline (PBS) that contained bovine serum albumin (BSA) $1 \%$ for 30 minutes at room temperature (RT). After washing, polyclonal rabbit anti-p65 antibody (ReI A) $1 \mu \mathrm{g} / \mathrm{mL}$, purchased from abcam (Ab6701), was used as primary antibody and incubated for 1 hour at RT. After washing, anti rabbit IgG antibody conjugated with Cy3 0.2 $\mu \mathrm{g} / \mathrm{mL}$ (Sigma Aldrich C2306) was used as secondary antibody and incubated for 30 minutes in RT. After washing, 4',6-diamidino-2-phenylindole (DAPI) was used as counter staining to mark the nuclear location.

\section{Visualization of NF-кB translocation}

Following counter staining and washing step, observation of nuclear translocation was performed under fluorescence microscopy (Zeiss, axio40 FL). Under ultra violet excitation, NF- $\kappa$ B protein labelled by Cy3 have an emission peak at $570 \mathrm{~nm}$ (red emission) and DNA labelled by DAPI have an emission peak at 461 $\mathrm{nm}$ (blue emission). They were visualized using filters that pass $605 / 70$ and $445 / 50$ emission respectively.

\section{Data analysis}

A positive microscopic examination of $\mathrm{NF}-\kappa \mathrm{B}$ translocation was defined as positive $\mathrm{Cy} 3$ staining in nuclear region on a per cell basis. The data were collected as percent nuclear positive staining from total cells 
observed per field of view. We used Mann-Whitney test for statistical analysis to compare differences between AFP-treated group and untreated group.

\section{RESULTS}

\section{LPS induces nuclear translocation of NF-кB}

Figure 1 showed cytoplasmic staining without nuclear labeling was observed in unactivated MDDC of control group. Activation with LPS for 30 minutes caused rapid nuclear translocation of NF- $\kappa$ B. This was also observed after 1 hour and 4 hours LPS activation, and then disappeared after 24 hours activation (data not shown). Based on this result, our experiment was then used 30 minutes as incubation period for LPS activation.

\section{AFP inhibits the nuclear translocation of NF-кB}

In contrast with the control group (Figure 2), the AFPtreated group did not show any nuclear staining of NF$\kappa \mathrm{B}$ following activation with LPS. Co-localization of Cy3 and DAPI signal inside the nucleus was not found. The NF- $\kappa$ B signal was only observed in cytoplasmic

\section{CONTROL}

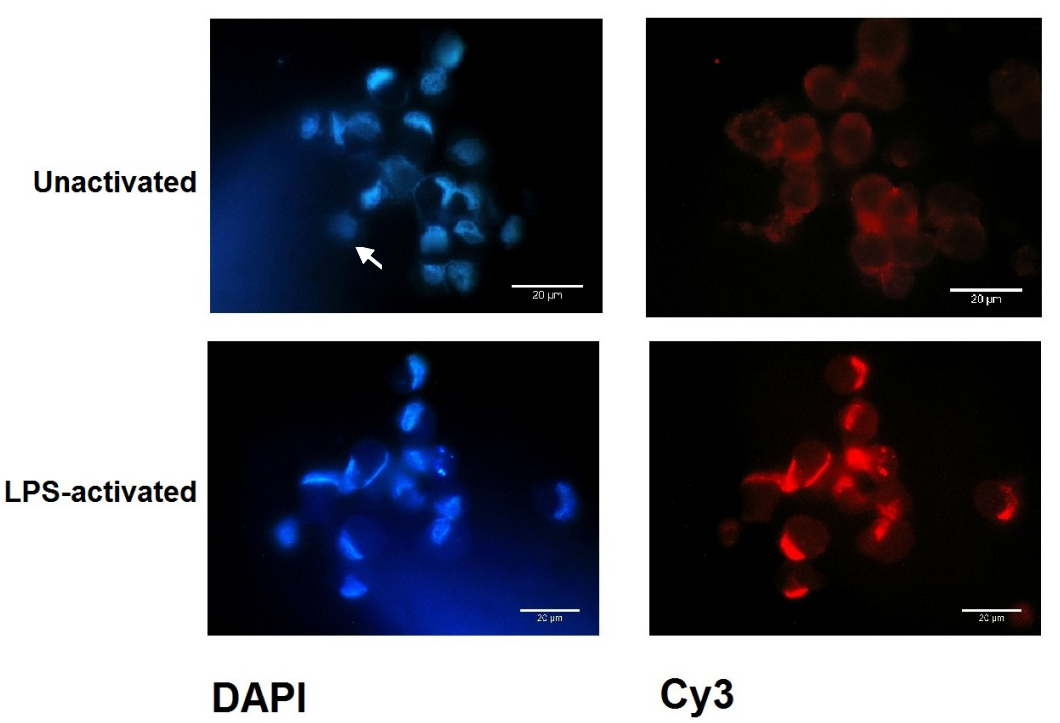

Figure 1. Nuclear translocation of $N F-\kappa B$ of the control group before (unactivated) and after LPS addition (LPS-activated) for 30 minutes. Magnification 1000x, scale bar $20 \mu \mathrm{m}$ relative to cell size. The arrow indicates positive DAPI staining and NF- $\kappa B$ labelling within similar cell. DAPI= blue staining, $N F-\kappa B C y 3=$ red staining

\section{AFP $6.25 \mathrm{ug} / \mathrm{ml}$}

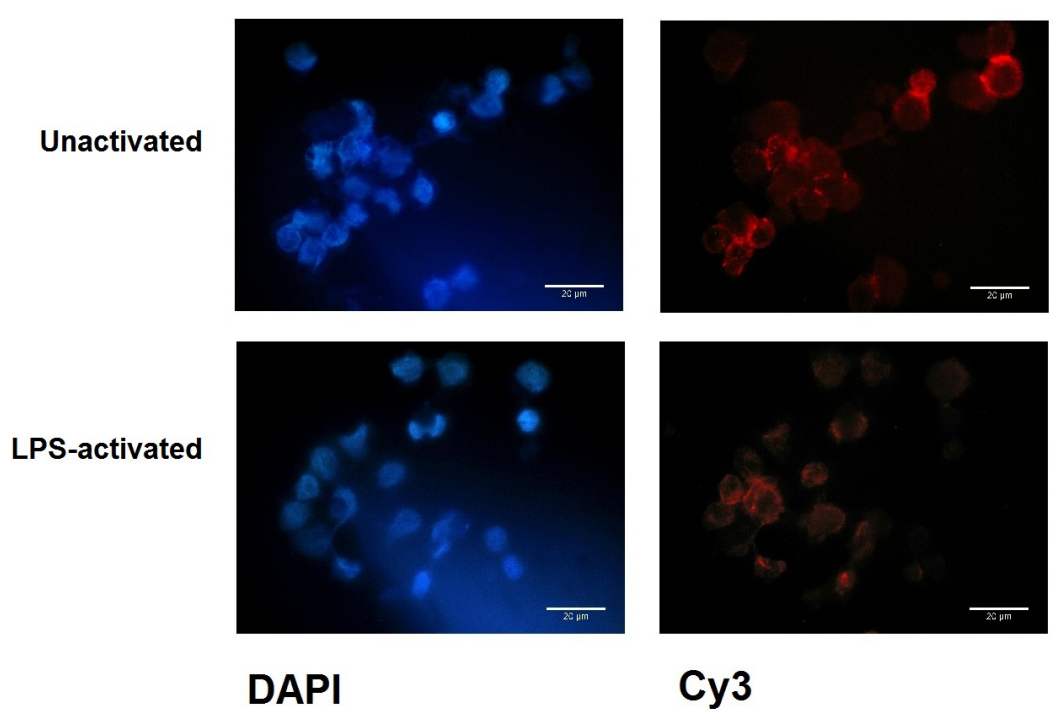

Figure 2. Nuclear translocation of NF- $\kappa B$ of the AFP-treated group before (unactivated) and after LPS addition (LPS-activated) for 30 minutes. Magnification 1000x, scale bar $20 \mu \mathrm{m}$ relative to cell size. DAPI= blue staining, $N F-\kappa B C y 3=$ red staining 


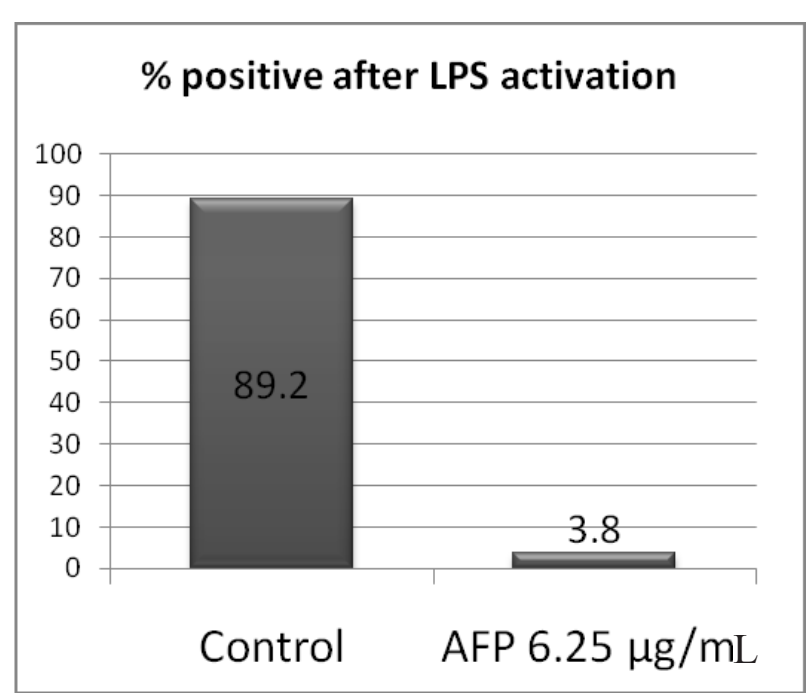

Figure 3. Comparison of mean of percentage of positive cells having NF- $\kappa B$ translocation after LPS activation between untreated group (control) and AFP-treated group (AFP $6.25 \mu \mathrm{g} / \mathrm{mL}$ ). The data were generated from three independent experiments $\left({ }^{*} p<0.001\right)$

compartment. Based on percentage of positive nuclear staining per field of view, we got a significantly different result between the control group compared to the AFPtreated group (Figure 3, Mann Whitney, $\mathrm{p}<0.001$ ).

\section{DISCUSSION}

Alpha fetoprotein has long been known as an oncofetal immunoregulator that has an effect on immune cells. Our previous study revealed that the addition of AFP on MDDC cultures at monocyte stage resulted in downregulation of MHC II expression, costimulatory molecules, maturation level and inhibition of IL12 synthesis after LPS activation. ${ }^{3}$ Dendritic cell dysfunction caused by the presence of tumor associated antigen such as AFP, can occur through several mechanisms: 1) impairment of dendritic cell formation, 2) inhibition of maturation process, 3) induction of apoptosis, and 4) interference with the process of antigen presentation. ${ }^{4}$

Several previous publications proved that NF- $\mathrm{kB}$ plays an important role in the maturation process of dendritic cells. NF- $\kappa \mathrm{B}$ activation occurs in mature dendritic cells in response to stimuli such as LPS or TNF $\alpha$ and is characterized by nuclear translocation of NF- $\mathrm{KB}$ followed by increased expression of MHC II molecules, costimulatory molecules and proinflammatory cytokine, IL-12. ${ }^{5,6}$ If the activation of NF- $\mathrm{kB}$ is inhibited, either pharmacologically or due to over expression of protein inhibitor, the maturation process will be inhibited. ${ }^{5,7}$

$\mathrm{NF}-\mathrm{\kappa B}$ is a heterodimer protein consisting of a $65 \mathrm{kDa}$ DNA binding sub unit (p65 or ReIA) and an associated
$50 \mathrm{kDa}$ protein (p50 or NF- $\mathrm{kB} 1$ ). In most cell types, the p50/p65 heterodimer is located within the cytoplasm as an unactivated complex form bound to its inhibitor, namely inhibitor kappa B (IאB), which prevents entry into the nucleus. Following cellular activation, i.e. LPS induction, I $\kappa \mathrm{B}$ is rapidly degraded allowing the $\mathrm{p} 65 \mathrm{sub}$ unit to translocate to the nucleus. ${ }^{6}$ In order to measure NF- $\mathrm{kB}$ translocation, we used polyclonal rabbit antip65 antibody (ReI A) that recognized residues 500 to the terminus of human NF- $\mathrm{kB}$ p65 sub unit of both unactivated form of NF- $\mathrm{kB}$ located inside the cytoplasm compartment and in activated form as p65 sub unit located inside the nucleus compartment.

In line with previous study, our result showed that LPS caused the activation of NF- $\mathrm{kB} .{ }^{5}$ In contrast to this fact, our AFP-treated group did not show nuclear positive labeling after LPS activation. These results indicate that the mechanism that is used by AFP in causing dendritic cell dysfunction is via NF-KB signaling pathway. Several mechanismshave been proposed to explain these inhibition: 1) the over-expression of protein inhibitor, ${ }^{7} 2$ ) inhibition of proteosome activity that prevent IKB degradation, ${ }^{8}$ 3) disruption of NF-kB-DNA binding activity. ${ }^{7}$ Our result showed that NF- $\mathrm{kB}$ was completely undetected in nuclear area, suggesting that the inhibition process occurs at the upstream level of this NF-kB signaling pathway. Further research will be needed to determine whether this inhibition caused by over expression of I $\mathrm{KB}$ or at earlier steps. There are many possibilities that can be explored to determine the specific target that are affected by AFP, but this experiment ensures that AFP plays role in the failure of nuclear translocation of NF- $\mathrm{KB}$.

In conclusion, this preliminary study demonstrated invitro that AFP prevented nuclear translocation of NF$\kappa B$ after LPS activation that lead to MDDC dysfunction as APC. This information can be used as a basic data for further understanding of immune suppression mechanism in HCC, where AFP is increased.

\section{Acknowledgment}

We thank to all persons who kindly participate and contribute to this study, in particular the blood donors. We also express our deepest gratitude to Dr. rer. nat. Ivet M. Suriapranata for critical reading and discussion. This research was supported by a grant from Mochtar Riady Institute for Nanotechnology.

\section{REFERENCES}

1. Mizejewski GJ. Biological roles of alpha-fetoprotein during pregnancy and perinatal development. Exp Biol Med. 2004;229:439-63. 
2. Mizejewsk GJ. Alpha-fetoprotein (AFP)-derived peptides as epitopes for hepatoma immunotherapy: a commentary. Cancer Immunol Immunother. 2009;58:159-70.

3. Setiyono A, Budiyati AD, Purwantomo S, Anggelia MR, Fanany I, Wibowo GA, et al. Immunoregulatory effect of AFP on monocyte-derived dendritic cell. BMC Immunol. 2011;12:4.

4. Charry AP, Maxwell T, Lopez JA. Dendritic cell dysfunction in cancer: a mechanism for immunosuppression. Immunol Cell Biol. 2005;83:451-61.

5. Rescigno M, Martino M, Sutherland CL, Gold MR, Castagnolia PR. Dendritic cell survival and maturation are regulated by different signaling pathways. J Exp Med. 1998;188(11):2175-80.
6. Blaecke A, Delneste Y, Herbault N, Jeannin P, Bonnefoy JY, Beck A, et al. Measurement of nuclear factor-kappa beta translocation on lipopolysaccharide-activated human dendritic cells by confocal microscopy and flow cytometry. Cytometry. 2002;48:71-9.

7. Yoshimura S, Bondenson J, Foxwell BM, Brennan FM, Feldmann M. Effective antigen presentation by dendritic cells is NF- $\mathrm{KB}$ dependent: coordinate regulation of MHC, co-stimulatory molecules and cytokine. Int Immunol. 2001;13:675-83.

8. Yang J, Bernier SM, Ichim TE, Li M, Xia X, Zhou D, et al. LF15-0195 generates tolerogenic dendritic cells by suppression of NF- $\mathrm{\kappa B}$ signaling through inhibition of IKK activity. J Leukoc Biol. 2003;74:438-47. 